\title{
OPTIMASI KEAMANAN VIRTUAL PRIVATE NETWORK UNTUK KOMUNIKASI DATA DI PUSAT INFORMASI PENGEMBANGAN PEMUKIMAN DAN BANGUNAN (PIP2B)
}

\author{
Diana $^{1}$, Javier Rezon Gumiri ${ }^{2}$, Ali Wandra ${ }^{3}$ \\ 1,2,3 Teknik Informatika Fakultas Teknik Universitas Muhammadiyah Bengkulu \\ Jl. Bali Kota Bengkulu, telp (0736) 22765/fax (0736) 26161 \\ diana@umb.ac.id \\ ${ }^{2}$ javierrezon1@gmail. com \\ 3aliwandra@gmail.com
}

\begin{abstract}
Abstrak: Keamanan, kemudahan dan kecepatan transfer (pertukaran data) adalah salah satu aspek yang penting dari suatu jaringan komunikasi, terutama untuk perusahaan-perusahaan skala menengah ke atas., sehingga jatuhnya informasi yang bersifat rahasia diambil dan dimanfaatkan oleh-oleh orang yang tidak bertanggung jawab akan menyebabkan kerugian yang besar, untuk mengatasi permasalahan ini perlu Virtual Private Network dan mengoptimalkan keamanan nya menggunakan metode Port Knocking dengan menutup semua port yang terbuka dan hanya mengijinkan koneksi yang telah melakukan tahap "knocking" terhadap port tertentu diperbolehkan melalukan koneksi server tersebut agar komunikasi data antara pihak Pusat Informasi Pengembangan Pemukiman dan Bangunan dengan Mitra kerjanya lebih mudah dan aman dalam menyelesaikan pekerjaannya, Hasil pengujaian dengan adanya jaringan ini di sana ada service atau layanan-layanan yang ada bisa berjalan sesuai harapan tanpa terhambat waktu dan tempat dan metode port knocking keamanan lebih optimal karena memerlukan pengetukan port dan protocol terlebih dahulu, jadi untuk hak akses ke server lebih aman tidak sembarang orang dapat mengakses jika tidak ada izin.
\end{abstract}

Kata Kunci: keamanan, Virtual Private Network, Port Knocking,

Abstract: Security, ease and speed of transfer (data exchange) is one of the important aspects of a communication network, especially for medium and high-scale companies, so that confidential information is taken and used by irresponsible people. causes great losses, to overcome this problem it is necessary to use a Virtual Private Network and optimize its security using the Port Knocking method by closing all open ports and only allowing connections that have done a "knocking" stage for certain ports to be allowed to do the server connection so that data communication between the Settlement and Building Development Information Center with its partners is easier and safer in completing the work, the results of testing with this network are there services or services that can run as expected without being hampered by time and place and the port knocking method security is more optimal because it requires tapping on the port and protocol first, so for safer access rights to the server, not just anyone can access it if there is no permission.

Keywords: security, Virtual Private Network, Port Knocking,

\section{Pendahuluan}

Pusat Informasi Pengembangan Pemukiman dan Bangunan (PIP2B) Bengkulu ' adalah suatu lembaga publik inovatif yang mendukung pembangunan dan menyediakan akses dan layanan informasi teknologi, konsultasi dan advokasi, serta meningkatkan kapasitas dan kompetensi pelaku penyelenggaraan pembangunan di bidang ke Cipta Karyaan. Berkaitan dengan hal tersebut, di PIP2B Kota Bengkulu belum adanya suatu jaringan 
Jurnal Pseudocode, Volume VIII Nomor 1, Februari 2021, ISSN 2355-5920, e-ISSN 2655-1845 www.ejournal.unib.ac.id/index.php/pseudocode

private yang dapat diakses oleh pihak perusahaan, sehingga masih ditemukan kendala-kendala apabila pihak perusahaan dan mitra kerja di PIP2B dalam menyelesaikan suatu pekerjaannya apabila dikerjakan dengan jarak jauh tanpa harus berada di lingkungan PIP2B dan semua data di input dan diakses melalui jaringan public (internet), Terdapat banyak user yang dapat dengan mudah mengakses jaringan lokal maupun internet, hal ini menjadi suatu masalah bagi administrator jaringan dalam mengelola user-user tersebut. Terutama pengelolaan terhadap user siapa saja yang boleh mengakses dan tidak terhadap jaringan tersebut.

Masalah keamanan, kemudahan dan kecepatan transfer (pertukaran data) adalah salah satu aspek yang penting dari suatu jaringan komunikasi, terutama untuk perusahaanperusahaan skala menengah ke atas. Teknologi internet dahulu digunakan oleh perusahaan atau instansi pemerintah maupun badan sebagai sebuah jaringan komunikasi yang terbuka yang penggunanya dapat mengakses, berbagi dan menambah informasi. sehingga jatuhnya informasi yang bersifat rahasia diambil dan dimanfaatkan oleh-oleh orang yang tidak bertanggung jawab akan menyebabkan kerugian yang besar, untuk mengatasi permasalahan ini perlu Virtual Private Network (VPN) dan mengoptimalkan keamanan nya menggunakan metode Port Knocking dengan menutup semua port yang terbuka dan hanya mengijinkan koneksi yang telah melakukan tahap "knocking" terhadap port tertentu untuk diperbolehkan melalukan koneksi VPN server tersebut dan agar komunikasi data antara pihak PIP2B dengan Mitra kerjanya lebih mudah dan aman dalam menyelesaikan pekerjaannya

Pada penelitian terdahulu Virtual Private Network adalah salah satu fasilitas yang ada pada server ClearOS yang memungkinkan para pekerja IT dapat mengakses jaringan internal kantor menggunakan koneksi jaringan pribadi dari luar dan Proxy Server dengan Metode Access Control List merupakan salah satu teknik selektivitas permintaan sambungan dalam komunikasi data untuk mengijinkan atau sebaliknya, sejumlah paket data dari suatu host komputer menuju ke tujuan tertentu dengan judul Implementasi Virtual Private Network Dan Proxy Server Menggunakan Clear Os Pada Pt.Valdo International[1]. Virtual Private Network mempunyai beberapa penerapannya termasuk jaringan Open vpn, jaringan ini merupakan teknologi yang digunakan untuk membangun jaringan vpn yang relative mudah dan murah serta konfigurasinya sangat mudah untuk server dan client. Open vpn juga memberikan keamanan dalam mentransfer data antar kantor cabang. Mengoptimalisasikan kinerja jaringan akan membantu keamanan, kecepatan dan penghematan bandwitch dalam suatu perusahaan dengan judul Perancangan Virtual Private Network Dan Optimalisasi Interkoneksi Mengunakan Teknologi Open vpn Pada PT. Tirta Musi Palembang [2].

Tujuan dari penelitian ini adalah untuk mengoptimalkan keamanan koneksi VPN menggunakan Metode Port knocking agar tidak sembarang orang bisa akses VPN Pusat Informasi Pengembangan Pemukiman dan Bangunan (PIP2B) Kota Bengkulu untuk komunikasi data, sehingga dapat memudahkan pekerjaan pihak perusahaan dan mitra kerjanya tanpa terhambat waktu, tempat dan terjamin keamanan datanya. 
Jurnal Pseudocode, Volume VIII Nomor 1, Februari 2021, ISSN 2355-5920, e-ISSN 2655-1845 www.ejournal.unib.ac.id/index.php/pseudocode

\section{LANDASAN TEORI}

\section{A. Jaringan Komputer}

Jaringan komputer adalah sebuah sistem yang terdiri atas komputer-komputer yang didesain untuk dapat berbagi sumber daya (printer, CPU), berkomunikasi (surel, pesan instan), dan dapat mengakses informasi (peramban web) penelitian dengan judul Jaringan Komputer Dan Pengertiannya, Jaringan memungkinkan manajemen sumber daya lebih efisien, misalnya, banyak pengguna dapat saling berbagi printer tunggal dengan kualitas tinggi, dibandingkan memakai printer kualitas rendah di masing-masing meja kerja dengan judul Memilih Topologi Jaringan Dan Hardware Dalam Desain Sebuah Jaringan Komputer, Dalam pengukuran kinerja koneksi jaringan komputer ini menggunakan metode QoS (Quality of Service) untuk mengetahui jumlah bandwidth, throughput, delay dan packet loss berdasarkan standar THIPON menggunakan metode action research, dengan tahapan penelitian melakukan diagnosing, action planning, action taking, evaluating dan learning perangkat jaringan komputer yang ada di SMK Teknologi Bistek Palembang agar dapat mengetahui kelemahan dari setiap node dan jaringan yang ada di SMK Teknologi Bistek Palembang [3]-[4]-[5].

B. Intranet

Intranet merupakan sebuah jaringan komputer berbasis protokol TCP/IP seperti internet, hanya saja digunakan dalam internal perusahaan, kantor, bahkan warung internet (WARNET) pun dapat dikategorikan intranet dan sistem ini akan menampilkan informasi mengenai hal-hal sesuai dengan apa yang dikehendaki oleh pembuat dengan judul Rancang Bangun Sistem Informasi Permintaan Atk Berbasis Intranet (Studi Kasus:
Kejaksaan Negeri Rangkasbitung) [6]. Dalam segi penggunaan, geografis maupun implementasinya, Intranet bekerja secara luas dan maksimal seperti halnya internet. Namun demikian Intranet sangat terbatas dalam hal privilege dan hak akses para pemakainya dengan judul Komputerisasi Pengolahan Data Penerimaan Peserta Didik Baru Di SMK Negeri 3 Pati Berbasis Intranet [7]. intranet sangat terbatas dalam hal privilege dan hak akses para pemakainya dengan judul Pengembangan Web Intranet Fisika Untuk Meningkatkan Penguasaan Konsep Dan Kemampuan Pemecahan Masalah Siswa SMK [8]. Intranet didefinisikan sebagai LAN (Local Area Network)/WAN (Wide Area Network) perusahaan yang menggunakan teknologi internet dan terlindungi oleh firewall perusahaan dengan judul Analisis dan perancangan sistem informasi dengan intranet: studi kasus persediaan material PT Balfour Beatty Sakti Indonesia [9].

C. Protokol

Protokol mendefinisikan apa yang dikomunikasikan, bagaimana dan kapan terjadinya komunikasi. Di mana program tersebut dapat membantu para pengguna komputer di dalam sebuah jaringan yang terkoneksi atau badan-badan hukum dalam pekerjaan sehingga dapat menghemat waktu, uang, dan tenaga dengan judul Pengembangan Aplikasi Pertukaran Pesan Berbasis Teks Melalui Jaringan Lokal (LAN) Menggunakan Microsoft Visual C++ 6.0 [10]. Dalam suatu jaringan komputer, terjadi sebuah proses komunikasi antar entiti atau perangkat yang berlainan sistemnya. Entiti atau perangkat ini adalah segala sesuatu yang mampu menerima dan mengirim. Untuk berkomunikasi mengirim dan menerima antara dua entity dibutuhkan pengertian di antara kedua belah pihak dengan Judul Rancang 
Jurnal Pseudocode, Volume VIII Nomor 1, Februari 2021, ISSN 2355-5920, e-ISSN 2655-1845 www.ejournal.unib.ac.id/index.php/pseudocode

Bangun Jaringan Komputer Dan Internet di Sekolah[11]. Protokol berfungsi untuk menghubungkan terminal pengirim dan penerima sehingga dalam berkomunikasi dan bertukar informasi dapat berjalan dengan baik dan benar penelitian dengan judul Sistem Telemetri Pemantauan Suhu Lingkungan menggunakan jaringan Mikrokontroler dan Jaringan WIFI [12].

D. Internet

Internet adalah suatu jaringan komputer yang sangat besar, terdiri dari jutaan perangkat komputer yang terhubung melalui suatu protocol tertentu untuk penukaran informasi antar komputer tersebut, Melalui internet orang dapat melakukan komunikasi dengan seseorang bahkan dengan beberapa komunitas sekaligus penelitian dengan judul Peranan Internet Terhadap Generasi Muda Di Desa Tounelet Kecamatan Langowan Barat [13]. Popularitas internet telah membuka banyak peluang ragam iklan yang dapat ditawarkan kepada publik antara lain: melalui Situs Jejaring Sosial (SJS), website, e-mail, video, widget, game, pop-up, instant messaging, dan lain-lain, Kehadiran internet memberikan revolusi fenomena dalam sejarah teknologi komunikasi masal penelitian dengan judul Internet Advertising Sebagai Media Komunikasi Pemasaran Interaktif [14]. Pada awalnya Internet atau WEB hanya dipergunakan untuk kepentingan Militer yaitu suatu tekhnologi yang dipergunakan untuk mengirimkan pesan melalui satelit, akan tetapi lama kelamaan teknologi tersebut akhirnya meluas, dan bahkan Internet pada saat ini sudah sama populernya dengan Telephone penelitian dengan judul Sistem Penjualan Berbasis Web (ECommerce) Pada Tata Distro Kabupaten Pacitan [15].

\section{E. Jaringan Virtual Private Network (VPN)} Jaringan Virtual Private Network (VPN) dengan memanfaatkan protokol EoiP, Ethernet over Internet Protokol (EoIP) merupakan protokol pada Mikrotik RouterOS yang berfungsi untuk membangun sebuah Network Tunnel antar MikroTik Router di atas sebuah koneksi TCP/IP yaitu dengan memanfaatkan koneksi internet sebagai penghubungnya penelitian dengan judul Implementasi Jaringan Virtual Private Network (VPN) Menggunakan Protokol EoIP[16]. Virtual Private Networkadalah teknologi jaringan komputer yang memanfaatkan media komunikasi public (open connection atau virtual circuits), seperti Internet, untuk menghubungkan beberapa jaringan local penelitian dengan judul nalisis Quality Of ServiceJaringan Virtual Private Network(VPN)di STMIK STIKOM Indonesia[17]. Aplikasi sistem informasi tersebut bisa diakses melalui internet secara private dengan teknologi VPN (Virtual Private Network). Namun dalam perkembangannya para administrator jaringan dituntut untuk bekerja dengan cepat, handal, dan profesional ketika terjadi masalah pada lalu lintas (traffic) yang disebabkan oleh penggunaan lalu lintas data secara overloaded dan akan mempengaruhi kecepatan koneksi antar perangkat jaringan, sehingga penggunaan internet tidak optimal dengan judul Aplikasi Network Traffic Monitoring Menggunakan Simple Network Management Protocol (SNMP) pada Jaringan Virtual Private Network (VPN) [18].

\section{F. Komunikasi Data}

Komunikasi data adalah proses pengiriman data atau informasi dari suatu sumber (disebut source) ke tujuan (disebut destination). Komunikasi data dapat dilakukan antara dua jenis komputer atau lebih yang jenisnya sama ataupun 
Jurnal Pseudocode, Volume VIII Nomor 1, Februari 2021, ISSN 2355-5920, e-ISSN 2655-1845 www.ejournal.unib.ac.id/index.php/pseudocode

berbeda dengan judul Komunikasi Data Dan Komputer [19]. Mata pelajaran komunikasi data bertujuan memberikan pemahaman dan penguasaan pengetahuan serta keterampilan tentang ragam aplikasi komunikasi data, proses komunikasi data dalam jaringan, aspek-aspek teknologi komunikasi data dan suara, dan kebutuhan telekomunikasi dalam jaringan dengan judul Pengembangan E-Modul Berbantuan Simulasi Berorientasi Pemecahan Masalah Pada MataPelajaran Komunikasi Data (Studi Kasus: Siswa Kelas XI TKJ SMK Negeri 3 Singaraja) [20].

\section{G. Port knocking}

Metode port knocking seorang administrator dapat meningkatkan keamanan suatu server dari berbagai seranagn yang ditujukan utuk layanan server. Cara kerja dari metode ini adalah server akan menerima percobaa koneksi dari client menuju port yang sudah ditentukan setelah itu firewall akan mendeteksi percobaan tersebut dan mengizinkan client untuk mengakses server. Setelah client selesai mengakses server firewall akan menutup kembali akses ke server sehingga server tidak bisa diakses kembali penelitian dengan judul Perancangan dan Implementasi Sistem Keamanan Jaringan Komputer Menggunakan Metode Port Knocking Pada Sistem Operasi Linux [21]. Port Knocking adalah salah satu sistem keamanan yang dapat melakukan fungsi yaitu mem-blok akses yang tidak diinginkan. Pada prinsipnya, port knocking bekerja menutup seluruh port yang ada di server. Bila user menginginkan akses ke server, user melakukan "ketukan" untuk menggunakan layanan, kemudian bila user telah selesai melakukan akses maka port ditutup kembali dengan judul Aplikasi Pengendalian Port dengan
Utilitas Port Knocking untuk Optimalisasi Sistem Keamanan Jaringan Komputer[22].

H. Firewall

Firewall adalah sistem dengan tujuan untuk melindungi. Perlindungan dapat dilakukan dengan menyaring, membatasi, atau bahkan menolak suatu atau semuahubungan/kegiatan dari suatu segmen pada jaringan pribadi dengan jaringan luar yang bukan merupakan ruang lingkupnya merupakan sebuah workstation, server,router, atau Local Area Network penelitian dengan judul paperblock akses browsing menggunakan mikrotik rb $751 \mathrm{u}-2 \mathrm{hnd}$ dengan schedule time (studi kasus: Disnakerpora Kota Bengkulu) [23]. Firewall merupakan salah satu solusi dalam mencegah serangan penyusup tersebut. Dengan mempelajari dengan seksama dan mengaturan hak akses yang dibutuhkan dalam suatu jaringan dan menggunakan software yang sesuai, maka kita dapat merancang firewall yang cocok untuk diterapkan. Firewall sendiri diterapkan untuk dapat melindungi dengan melakukan filtrasi, membatasi ataupun menolak suatu koneksi pada jaringan dengan judul Desain dan Implementasi Firewall dengan Layer 7 Filter Pada Jaringan Teknik Elektro[24].

\section{METODE PENELITIAN}

\section{A. Metode Pengembangan Sistem}

Network Development Life Cycle (NDLC) merupakan sebuah metode yang bergantung pada proses pembangunan sebelumnya seperti perencanaan strategi bisnis, daur hidup pengembangan aplikasi, dan analisis pendistribusian data, langkah-langkahnya sebagai berikut :

\section{Analysis}

Tahap awal ini dilakukan analisa kebutuhan, analisa permasalahan yang muncul, analisa 
Jurnal Pseudocode, Volume VIII Nomor 1, Februari 2021, ISSN 2355-5920, e-ISSN 2655-1845 www.ejournal.unib.ac.id/index.php/pseudocode

keinginan pengguna, dan analisa topologi jaringan yang sudah ada saat ini

2. Simulation Prototype.

Beberapa pekerja jaringan akan membuat dalam bentuk simulasi dengan bantuan tools khusus di bidang network seperti Boson, Packet Tracert, Netsim, dan sebagainya

3. Implementation.

Pada tahapan ini akan memakan waktu lebih lama dari tahapan sebelumnya. Dalam implementasi pekerja jaringan akan menerapkan semua yang telah direncanakan dan didesain sebelumnya

4. Monitoring.

Setelah implementasi tahapan monitoring merupakan tahapan yang penting, agar jaringan komputer dan komunikasi dapat berjalan sesuai dengan keinginan dan tujuan awal dari user pada tahap awal analisis, maka perlu dilakukan kegiatan monitoring.

\section{Management.}

Pada level manajemen atau pengaturan, salah satu yang menjadi perhatian khusus adalah masalah kebijakan (policy). Kebijakan perlu dibuat untuk membuat/mengatur agar sistem yang telah dibangun dan berjalan dengan baik dapat berlangsung lama dan unsur reliability terjaga.
B. Flowchart Penerpan Port Knocking

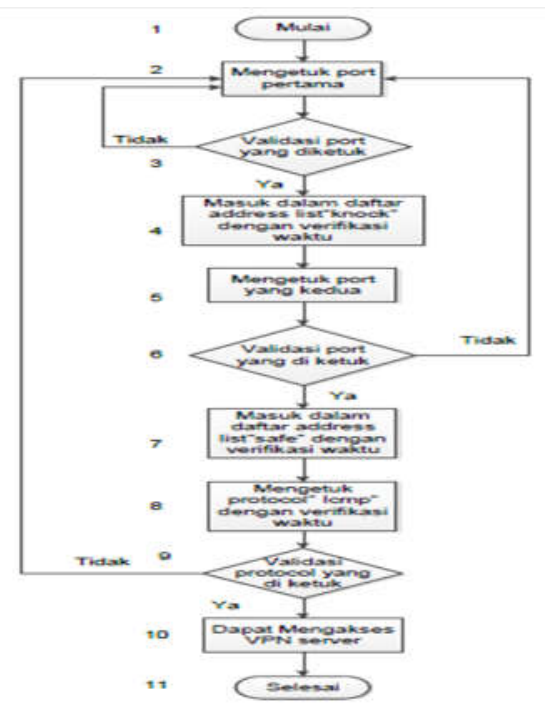

Gambar 1. Penerapan Port Knocking

c. Tahapan-Tahapan Sistem

Berikut gambaran tahapan-tahapan proses penerapan Port Knocking pada sistem:

1. Nomor 1 proses memulai akan melakukan knocking port.

2. Nomor menunjukan proses mengetuk port tahap pertama.

3. Nomor 3 validasi port yang akan di ketuk, apabila port yang diketuk sudah benar maka ip addressnya akan dikelompokan pada address list"knock", apabila salah akan diulang ke proses Nomor 2.

4. Nomor 4 menunjukan ip address yang mengetuk sesuai dengan port yang telah diatur akan dikelompokan dalam address list "knock". dalam waktu 15 detik jika tidak melakukan ketukan port selanjutnya, maka proses akan diulangi dari Nomor 2.

5. Nomor 5 menunjukan proses mengetuk port tahap kedua.

6. Nomor 6 validasi port yang akan di ketuk, apabila port yang diketuk sudah benar maka ip addressnya akan dikelompokan pada address list"safe", apabila salah akan diulang ke proses Nomor 2.

7. Nomor 7 menunjukan ip address yang mengetuk sesuai dengan port yang telah diatur akan dikelompokan dalam address list "safe". dalam waktu 30 detik jika tidak 
Jurnal Pseudocode, Volume VIII Nomor 1, Februari 2021, ISSN 2355-5920, e-ISSN 2655-1845 www.ejournal.unib.ac.id/index.php/pseudocode

melakukan ketukan selanjutnya, maka proses akan diulangi dari Nomor 2.

8. Nomor 8 menunjukan proses mengetuk protocol Icmp. Dan akan dikelompokan dalam address list "ping". dalam waktu 3 menit.

9. Nomor 9 validasi port yang akan di ketuk, apabila port yang diketuk sudah benar maka sudah dapat mengakses VPN server apabila salah akan diulang ke proses Nomor 2.

10. Nomor 10 ip address yang telah berada pada address list "ping" yang telah melakukan ketukan protocol "icmp" akan diperkenankan untuk mengakses VPN server.

11. Nomor 11 selesai.

\section{HASIL DAN PEMBAHASAAN}

A. Hasil

a. Instalasi Mikrotik RouterBoard 750

RB750 adalah produk routerboard yang sangat mungil dan diperuntukkan bagi penggunaan SOHO. Memiliki 5 buah port ethernet 10/100, dengan prosesor baru Atheros 400MHz. Sudah termasuk dengan lisensi level 4 dan adaptor $12 \mathrm{~V}$.



Gambar 2. Mikrotik RouterBoard 750

b. Konfigurasi Mikro Router Board 750

Proses konfigurasi Mikrotik bertujuan agar Mikrotik dapat digunakan untuk menghubungkan Mitra ke VPN PPTP di PIP2B sesuai pada rancangan jaringan yang telah di buat.

1. Menambahkan IP address pada LAN (Local area Network) untuk jaringan lokal.

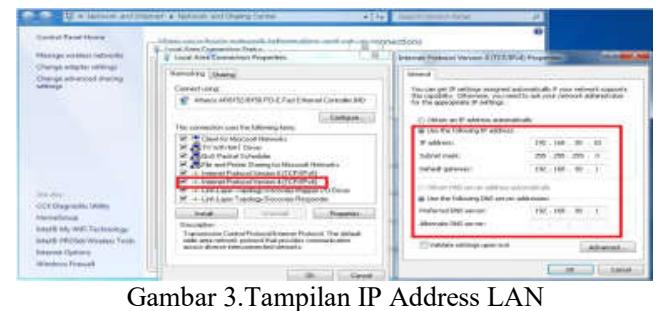

2. Jalankan aplikasi winbox lalu connect untuk masuk kedalam Mikrotik.

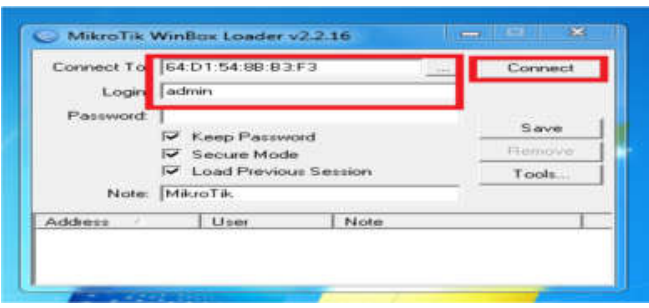

Gambar 4. Tampilan Login Menggunakan Aplikasi Winbox

3. Menambahkan IP address pada mikrotik interface 2 agar mikrotik dapat memberikan jalur koneksi ke jaringan lokal



4. Membuat DHCP Client agar jaringan lokal otomatis terhubung dengan jaringan publik /

ISP (Internet Service Provider).

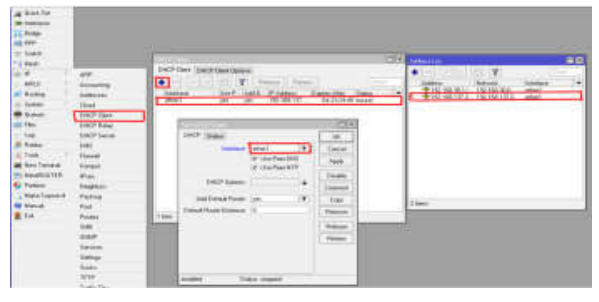

Gambar 6. Tampilan DHCP Client dan IP dari ISP

5. Menambahkan DNS dan mencentang "Allow Remote Request" agar client dapat merequest DNS dari Mikrotik.

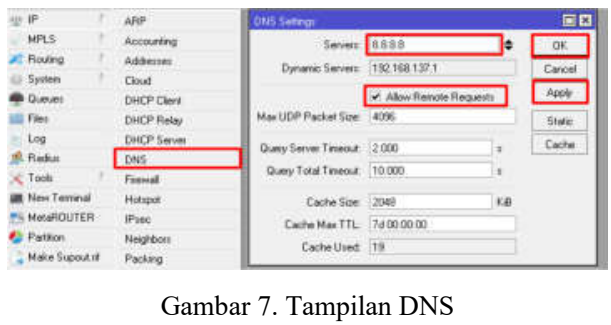

6. Menambahkan NAT (Network Address Translation) yang bertujuan untuk 
Jurnal Pseudocode, Volume VIII Nomor 1, Februari 2021, ISSN 2355-5920, e-ISSN 2655-1845 www.ejournal.unib.ac.id/index.php/pseudocode



c. Konfigurasi VPN PPTP Router Server

Selanjutnya untuk membuat PPTP server dengan menggunakan aplikasi winbox. Dalam membuat PPTP server ada beberapa tahapan yang di-setting :

1. Mengaktifkan fitur PPTP server bertujuan agar bisa membuat profile PPTP untuk Mitra.

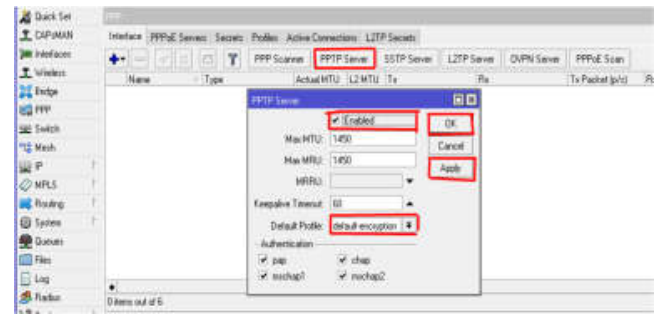

Gambar 9. Tampilan Mengaktifkan PPTP Server

2. Membuat user VPN Mitra bertujuan untuk membuat User dan password Mitra pada saat ingin terhubung ke dalam VPN Server



Gambar 10. Tampilan Membuat User Dan Password VPN Mitra

3. Membuat user VPN remote acces bertujuan untuk membuat user dan password Mitra pada saat ingin terhubung ke dalam VPN
Server ketika tidak berada di bawah router Mitra.

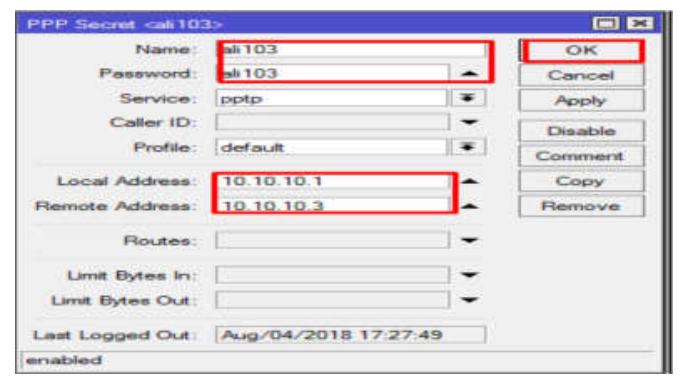

Gambar 11. Tampilan Membuat User Dan Password Remote Acces

4. Membuat IP address komputer server, bertujuan untuk dijadikan sebagai IP komputer server PIP2B.

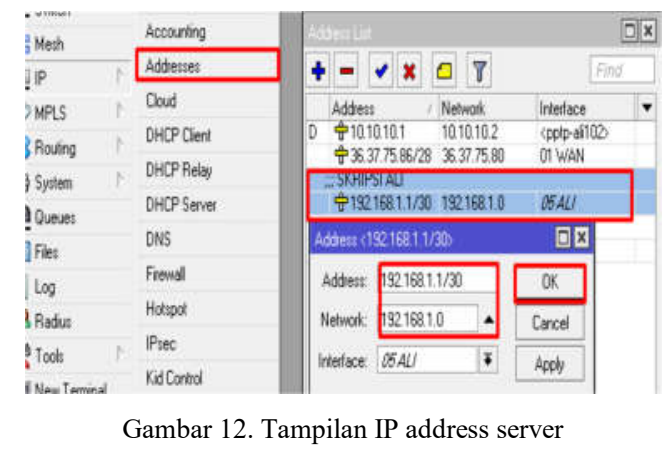

5. Membuat IP route, bertujuan sebagai jalur koneksi antara server dan mitra agar bisa terhubung.

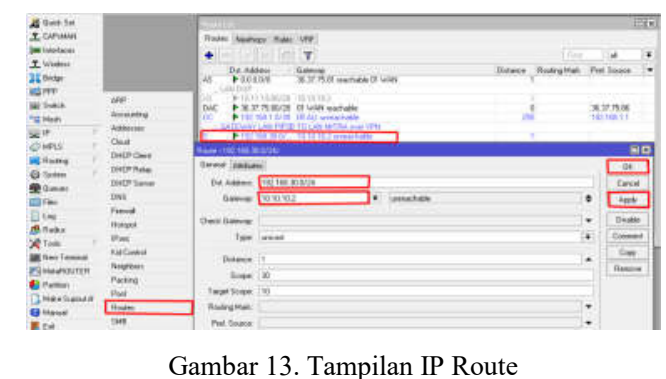

d. Konfigurasi VPN PPTP Router Mitra

Selanjutnya untuk membuat PPTP Mitra. Dalam membuat PPTP Mitra ada beberapa tahapan yang di-setting :

1. Membuat PPTP Client dengan memasukan user dan password yang telah di buat di PPTP Server. 
Jurnal Pseudocode, Volume VIII Nomor 1, Februari 2021, ISSN 2355-5920, e-ISSN 2655-1845 www.ejournal.unib.ac.id/index.php/pseudocode

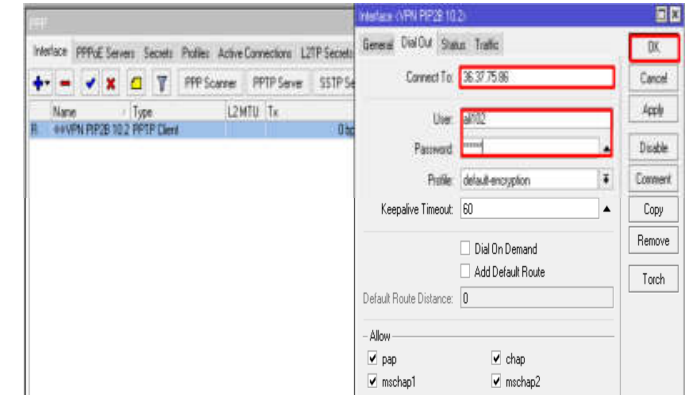

Gambar 14. Tampilan PPTP Client

2. Membuat IP route, Membuat IP route bertujuan untuk jalur koneksi antara Mitra dan Server agar bisa terhubung

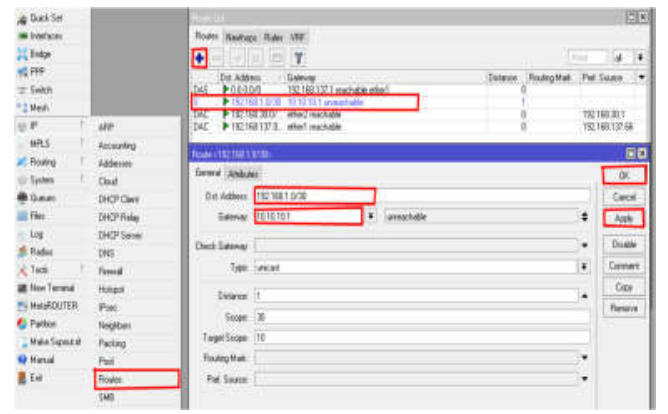

Gambar 15. .Tampilan IP Route

\section{e. Konfigurasi Port Knocking}

Selanjutnya tahap konfigurasi port knocking pada VPN Server untuk mem-filter Mitra yang mengakses VPN Server PIP2B. Berikut adalah langkah-langkah dalam konfigurasi port knocking pada Mikrotik:

1. Membuat rule 1 pada firewall, yang bertujuan jika ada koneksi dari luar ke dalam mengetuk port 1122 dengan protocol tcp maka tersebut akan dimasukan kedalam kelompok addresslist "knock" selama 15 detik.

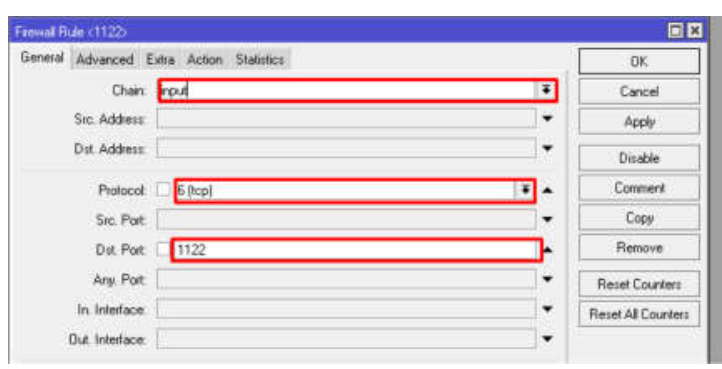

Gambar 16. Tampilan Firewall General rule 1

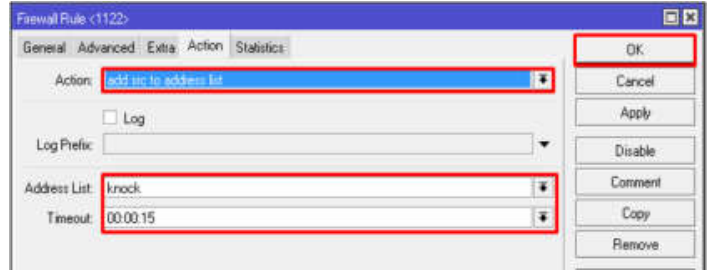

Gambar 17. Tampilan Firewall action rule 1

2. Membuat rule 2 pada firewall, yang bertujuan jika ada koneksi dari luar ke dalam yang berada pada kelompok address list "knock" mengetuk port 1233 dengan protocol tcp maka ip tersebut akan dimasukan kedalam kelompok addresslist "safe" selama 30 detik



Gambar 18. Tampilan Firewall General rule 2

General Advanced Extra Action Statistics
Sic. Address List. knock
Dst Address List:

Gambar 19. Tampilan advanced rule 2

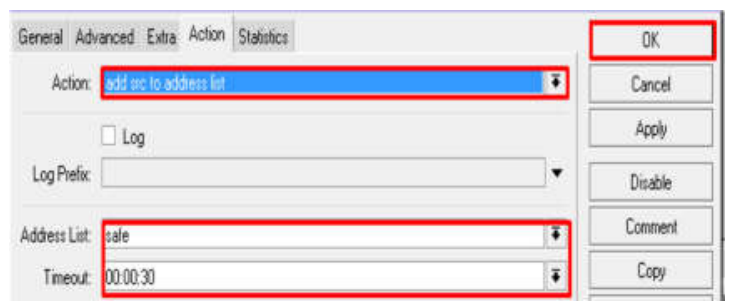

Gambar 20. Tampilan Action Rule 2

3. Membuat rule 3 pada firewall, yang bertujuan jika ada koneksi dari luar ke dalam yang berada pada kelompok address list "safe" melakukan ping maka ip tersebut akan dimasukan kedalam kelompok address-list "ping” selama 3 menit. 
Jurnal Pseudocode, Volume VIII Nomor 1, Februari 2021, ISSN 2355-5920, e-ISSN 2655-1845

www.ejournal.unib.ac.id/index.php/pseudocode



Gambar 21. Tampilan Firewall Genera

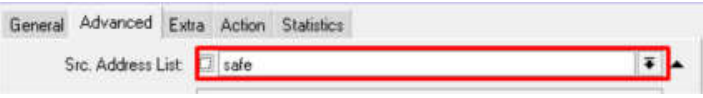

Gambar 22. Tampilan Firewall advanced

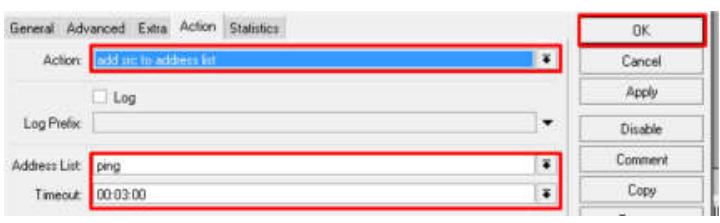

Gambar 23. Tampilan Firewall Action

4. Membuat rule 4 pada firewall, yang bertujuan jika ada koneksi dari luar ke dalam yang berada pada kelompok address list "ping” mengetuk protocol "icmp" maka ip tersebut akan di izinkan untuk mengakses vpn server.



General Advanced Extra Action Statistics
Src. Addess List 1 ping

Gambar 25. Tampilan Firewall advanced

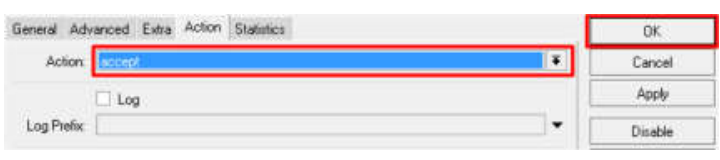

Gambar 26. Tampilan Firewall Action

5. Membuat rule 5 pada firewall, yang bertujuan jika ada koneksi dari luar ke dalam yang tidak berada pada kelompok address list "ping” maka ip tersebut tidak akan di izinkan mengakses vpn server.

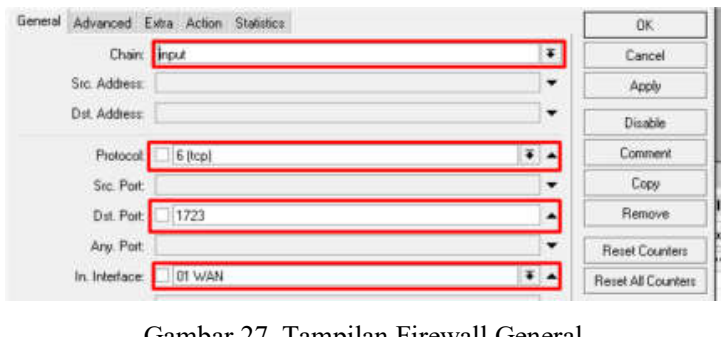

Gambar 27. Tampilan Firewall General

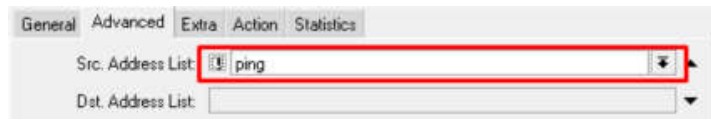

Gambar 28. Tampilan Firewall Advanced

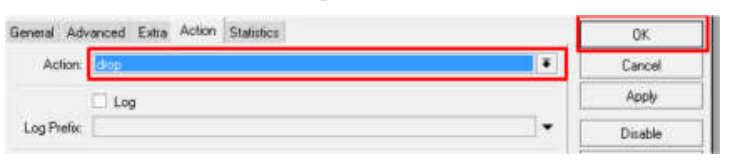

Gambar 29. Tampilan Firewall Action

\section{f. Konfigurasi VPN Mitra Remote Acces}

Penggunaan VPN untuk Mitra adalah menghubungkn Mitra dengan network VPN Server seolah-olah berada dalam satu jaringan local. Dalam mengkoneksikan Mitra dengan VPN server dibutuhkan beberapa tahapan settingan pada Komputer Mitra. Berikut adalah settingansettingan user untuk koneksi ke VPN menggunakan Microsoft Windows .

1. Buat koneksi baru dengan cara masuk ke control panel kemudian klik windows network and internet lalu klik set up a new connection or network.



Gambar 30. Tampilan Control Panel $>$ Network And Internet

2. Menambahkan koneksi baru "Connect to a workplace" yg bertujuan membuat koneksi jaringan baru. 
Jurnal Pseudocode, Volume VIII Nomor 1, Februari 2021, ISSN 2355-5920, e-ISSN 2655-1845 www.ejournal.unib.ac.id/index.php/pseudocode

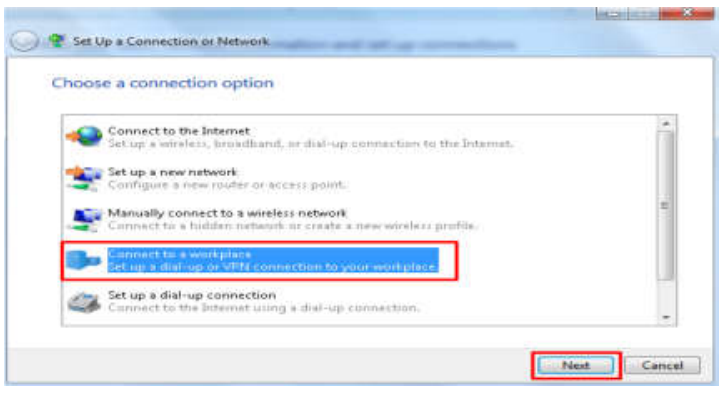

Gambar 31. Tampilan Set Up A Connection Or Network

3. Lalu klik "use my internet connection (VPN)" yang bertujuan untuk memilih koneksi VPN yang akan di buat.

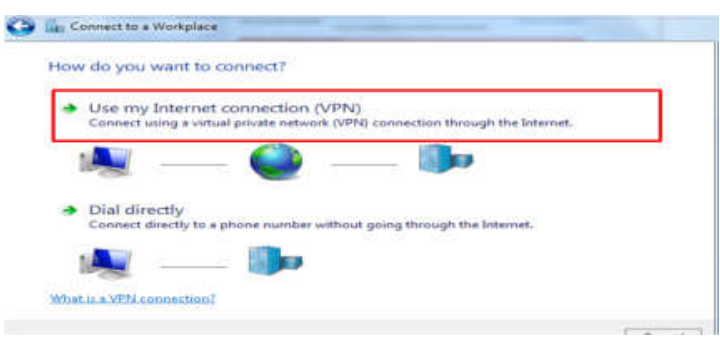

Gambar 32. Tampilan Connect To A Workplace

4. Selanjutnya masukan user dan password VPN yang telah dibuat.



Gambar 33. Tampilan user dan password

5. Koneksi VPN yang telah di buat telah tersedia.

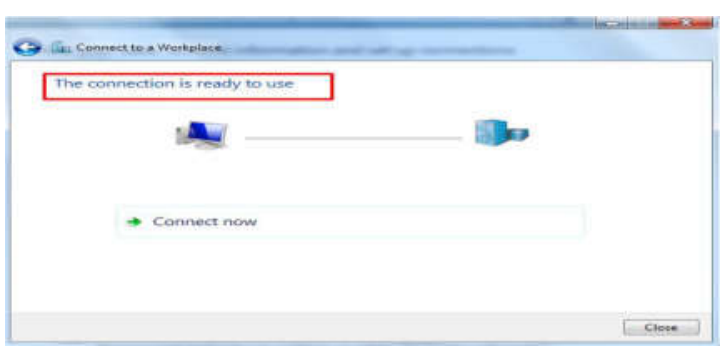

Gambar 34. Tampilan Koneksi VPN Yang Telah Dibuat g. Monitoring

Pada tahap ini akan dilakukan monitoring terhadap system VPN yang telah dibuat yaitu dengan melakukan analisa system VPN. Pengujian dilakukan dengan cara melalukan pengujian login, dan file sharing.

B. Pembahasaan

Setelah semua yang diperlukan untuk membangun system VPN selesai, maka ada beberapa scenario yang akan dilakukan untuk melakukan peengujian terhadap jaringan VPN. Pada pengujian ini akan dilakukan scenario pertama pengujian yang terdiri atas dua pengujian diantaranya:

Tabel 1. Pengujian Login Data Benar

\begin{tabular}{ll}
\hline \multicolumn{1}{c}{ Kasus dan hasil uji (Data Benar) } \\
\hline Data Masukan & Menggunakan ketukan \\
Yang & Ketukan, user dan password \\
diharapkan & $\begin{array}{l}\text { (remoteaccess) yang } \\
\text { dimasukan benar sehingga } \\
\text { dapat terhubung VPN }\end{array}$ \\
Pengamatan & $\begin{array}{l}\text { Ketukan,user dan password } \\
\text { yang dimasukan diterima dan } \\
\text { terhubung ke VPN dan File } \\
\text { sharing bias di akses }\end{array}$ \\
& Di terima \\
\hline
\end{tabular}

1. Pengujian data benar dilakukan dengan cara masuk "command prompt" lakukan Ketukan pertama knock 36.37.75.86 1122:tcp. Akan muncul koneksi yang mengetuk di jendela "Firewall" dan di kelompokan ke dalam address list "knock" dengan waktu 15 detik.



Gambar 35. Tampilan Ketukan Pertama

2. Pengetukan ke dua dilakukan dengan cara knock 36.37.75.86 1122:tcp dalam waktu 15 detik dan Akan muncul koneksi yang mengetuk di jendela "Firewall" dan di kelompokan ke dalam address list "safe" 
Jurnal Pseudocode, Volume VIII Nomor 1, Februari 2021, ISSN 2355-5920, e-ISSN 2655-1845 www.ejournal.unib.ac.id/index.php/pseudocode



Gambar 36. Tampilan Ketukan Ke Dua

3. Setelah itu mengetukan protocol "icmp" dalam waktu 30 detik dan Akan muncul koneksi yang mengetuk di jendela "Firewall" dan di kelompokan ke dalam address list "ping" dengan waktu 3 menit. Jika tidak berhasil maka akan mengulang pada pengetukan pertama.

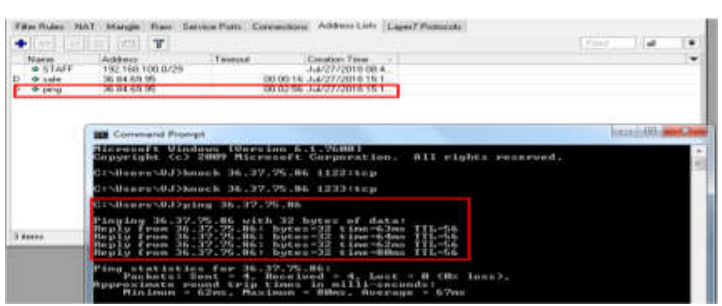

Gambar 37. Tampilan Koneksi Protocol "Icmp"

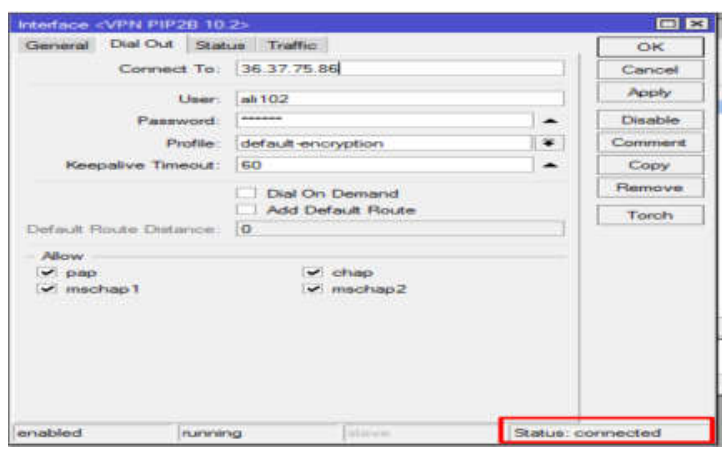

Gambar 38. Tampilan Koneksi Mitra Yang Terhubung

4. Ketika pengetukan telah dilakukan. Komputer yang berada di bawah router sudah langsung terhubung otomatis kedalam VPN.



Gambar 39. Tampilan Login VPN Remote Acces

5. Untuk remote access harus melakukan login manual user dan password kedalam koneksi VPN yang telah di buat

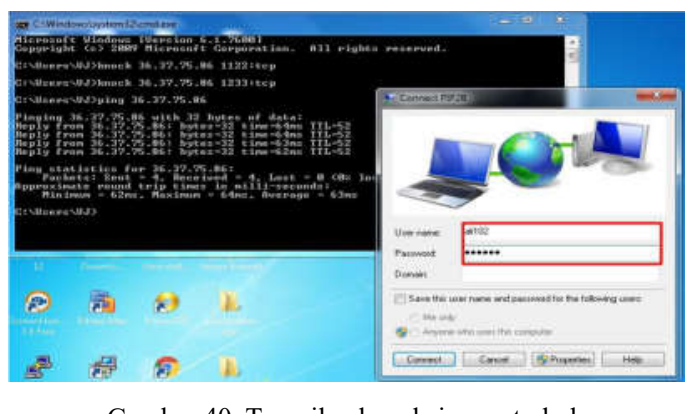

Gambar 40. Tampilan koneksi yang terhubung

6. Dan dapat dilihat sekarang Mitra sudah terkoneksi ke VPN PIP2B

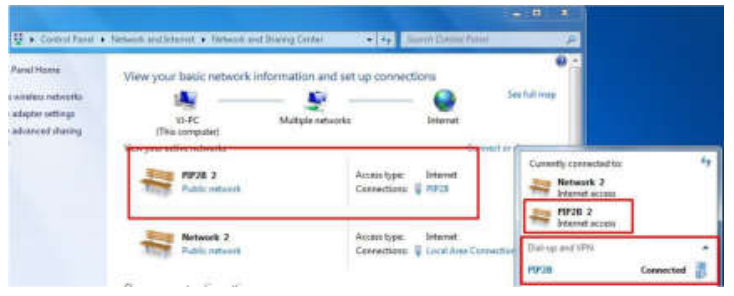

Gambar 41. Tampilan Komputer Server PIP2B

7. Dan sekarang data komputer server PIP2B sudah bisa akses dan Sharing data sudah bisa dilakukan

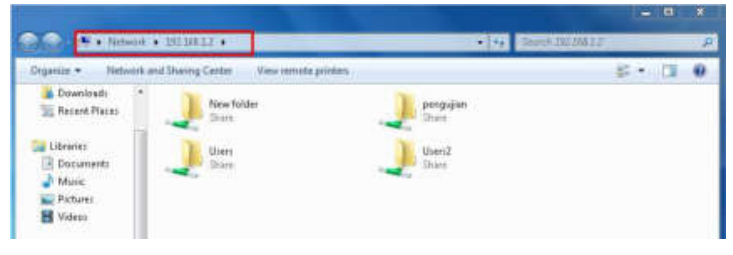

Gambar 42. Tampilan Komputer Server PIP2B 
Jurnal Pseudocode, Volume VIII Nomor 1, Februari 2021, ISSN 2355-5920, e-ISSN 2655-1845 www.ejournal.unib.ac.id/index.php/pseudocode

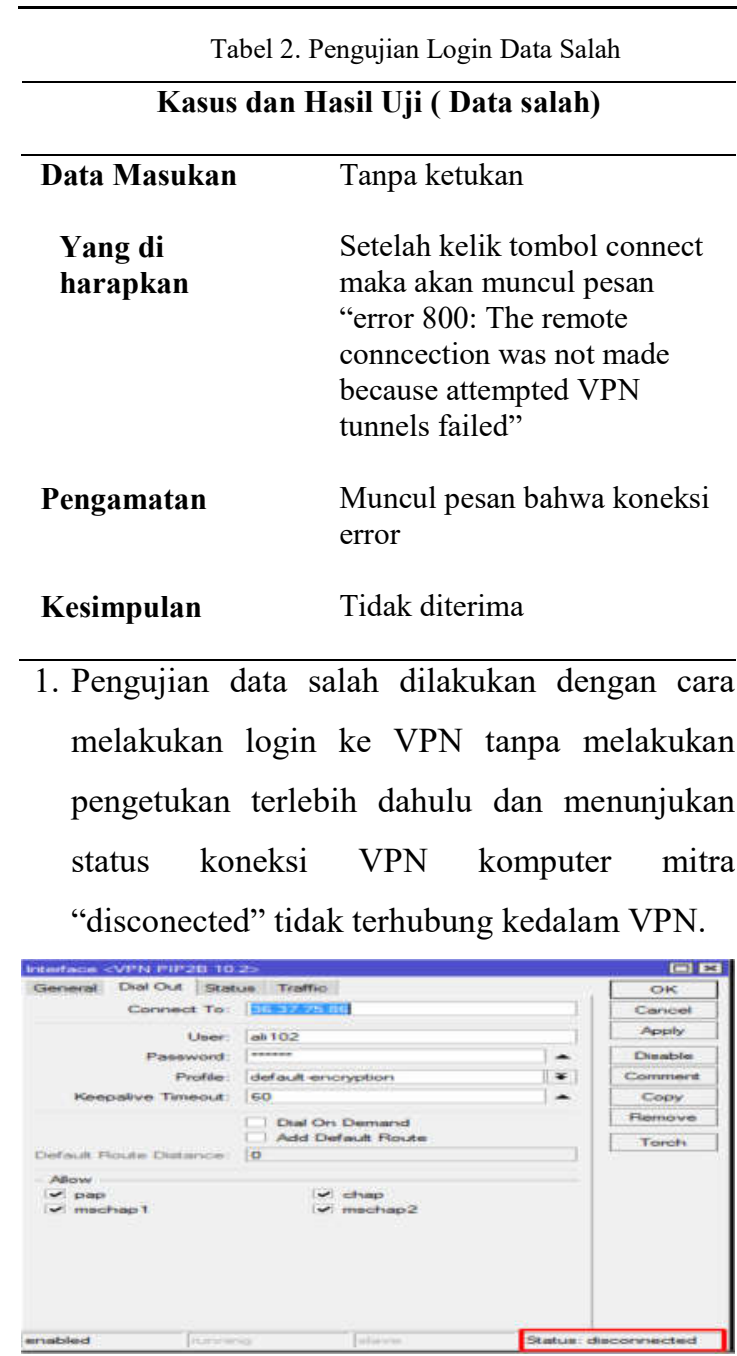

Gambar 43. Tampilan Status VPN Komputer Mitra



Gambar 44. Tampilan Login User Dan Password Remote Acces

2. Pada remote acces setelah langsung melakukan login tanpa mengetuk muncul pesan koneksi ke vpn eror dan tidak bisa terkoneksi ke jaringan VPN.

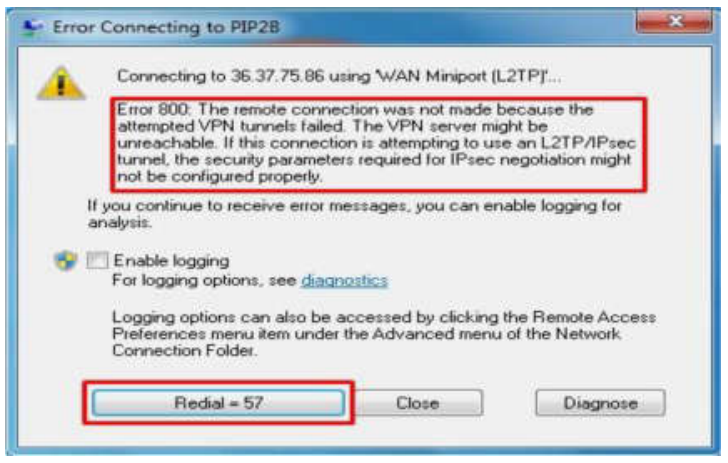

Gambar 45. Tampilan Koneksi VPN Eror

\section{KESIMPULAN}

Berdasarkan hasil Pengujian: 1) VPN Server PIP2B bisa diakses oleh Mitra Kerjanya dan remote acces selama Server memberikan hak akses "autentikasi" untuk masuk kedalam , 2) Dengan adanya metode port knocking keamanan lebih optimal karena memerlukan pengetukan port dan protocol terlebih dahulu, jadi untuk hak akses ke VPN Server lebih aman dan tidak sembarang orang yang bisa akses jika tidak mendapatkan hak akses "autentikasi" tersebut,, 3) Dengan adanya jaringan VPN di PIP2B, service atau layananlayanan yang ada di PIP2B bisa berjalan sesuai harapan tanpa terhambat waktu dan tempat.

\section{REFERENSI}

[1] T. M. Eka Wida Fridayanthie1, "Rancang Bangun Sistem Informasi Permintaan Atk Berbasis Intranet (Studi Kasus: Kejaksaan Negeri Rangkasbitung),' J. Tek. Komput. Amik Bsi, vol. 1, no. 1, pp. 55-66, 2015.

[2] T. Openvpn, P. Pt, T. Musi, S. Sarial, A. Wijaya, and E. P. Agustini, "Perancangan Virtual Private Network Dan Optimalisasi Interkoneksi Mengunakan.”

[3] M. J. N. Yudianto, "Jaringan Komputer dan Pengertiannya," Ilmukomputer.Com, vol. Vol.1, pp. 1$10,2014$.

[4] A. Supriyadi and D. Gartina, "Memilih Topologi Jaringan dan Hardware dalam Desain Sebuah Jaringan Komputer," Inform. Pertan., vol. 16, no. 2, pp. 10371053, 2007.

[5] A. Putri, Fatoni, and I. Solikin, "Analisa Kinerja Koneksi Jaringan Komputer Pada Smk Teknologi Bistek Palembang," Univ. Bina Darma, no. 12, pp. 1-11, 2016. 
Jurnal Pseudocode, Volume VIII Nomor 1, Februari 2021, ISSN 2355-5920, e-ISSN 2655-1845 www.ejournal.unib.ac.id/index.php/pseudocode

[6] T. M. Eka Wida Fridayanthie1, "Rancang Bangun Sistem Informasi Permintaan Atk Berbasis Intranet (Studi Kasus: Kejaksaan Negeri Rangkasbitung)," $J$. KHATULISTIWA Inform., vol. 20, no. 1, pp. 1-8, 2016.

[7] R. N. Hidayatiur, "Komputerisasi Pengolahan Data Penerimaan Peserta Didik Baru Di Smk Negeri 3 Pati Berbasis Intranet," J. Speed - Sentra Penelit. Eng. dan Edukasi, vol. 5, no. Laporan TA 2013, pp. 01-07, 2013.

[8] A. Doyan, "Pengembangan Web Intranet Fisika Untuk Meningkatkan Penguasaan Konsep Dan Kemampuan Pemecahan Masalah Siswa Smk," Indones. J. Phys. Educ., vol. 10, no. 2, pp. 117-127, 2014, doi: 10.15294/jpfi.v10i2.3447.

[9] S. Darudiato and K. Punta, “Analisis Dan Perancangan Sistem Informasi Dengan Intranet: Studi Kasus Persediaan Material Pt Balfour Beatty Sakti Indonesia," CommIT (Communication Inf. Technol. J., vol. 1, no. 1, p. 95, 2007, doi: 10.21512/commit.v1i1.471.

[10] D. Wahyuni and S. Hadi, "Pengembangan Aplikasi Pertukaran Pesan Berbasis Teks Melalui Jaringan Lokal ( LAN ) Menggunakan Microsoft Visual C ++ 6 . 0," vol. $07,2008$.

[11] T. Tristono1) and Santi Dwi Nurhumam2), "Dalam suatu jaringan komputer, terjadi sebuah proses komunikasi antar entiti atau perangkat yang berlainan sistemnya. Entiti atau perangkat ini adalah segala sesuatu yang mampu menerima dan mengirim. Untuk berkomunikasi mengirim dan menerima antara dua en," vol. 14, pp. 42 49, 2013.

[12] Munarso and Suryono, "Menggunakan Mikrokontroler Dan Jaringan Wifi," Youngster Physic J., vol. 3, no. 3, pp. 249-256, 2014.

[13] M. Sumolang, "Peranan Internet Terhadap Generasi Muda Di Desa Tounelet Kecamatan Langowan Barat," J. TEKNOIF, vol. 3, no. 2, p. 19, 2013, doi: 2338-2724.

[14] E. Hariningsih, "Internet Advertising Sebagai Media Komunikasi Pemasaran Interaktif,” Jbma, vol. I, no. 2, pp. 12-16, 2013.

[15] M. Ahmia and H. Belbachir, "p, q-Analogue of a linear transformation preserving log-convexity," Indian J. Pure Appl. Math., vol. 49, no. 3, pp. 549-557, 2018, doi: 10.1007/s13226-018-0284-5.

[16] H. Kuswanto, "Implementasi Jaringan Virtual Private Network (VPN) Menggunakan Protokol EoIP," Paradigma, vol. 19, no. 1, pp. 46-51, 2017.

[17] I. K. S. Satwika, "Analisis Quality of Service Jaringan Virtual Private Network (Vpn) Di Stmik Stikom
Indonesia," J. Ilm. Inform., vol. 7, no. 01, p. 60, 2019, doi: $10.33884 /$ jif.v7i01.1016.

[18] N. Lizarti, “Aplikasi Network Traffic Monitoring Menggunakan Simple Network Management Protocol ( SNMP ) pada Jaringan Virtual Private Network ( VPN ) Menggunakan Simple Network Management Protocol ( SNMP ) pada Jaringan Virtual Private Network ( VPN ) Wirta Agustin,” no. June 2015, 2018.

[19] W. Stallings, "Komunikasi Data dan Komputer Dasardasar komunikasi data,” no. April, p. 444, 2001.

[20] . K. A. P., . D. K. A. S. S. M. S., and . G. S. S. S. T. . M. C., "Pengembangan E-Modul Berbantuan Simulasi Berorientasi Pemecahan Masalah Pada Mata Pelajaran Komunikasi Data (Studi Kasus: Siswa Kelas XI TKJ SMK Negeri 3 Singaraja)," Kumpul. Artik. Mhs. Pendidik. Tek. Inform., vol. 6, no. 1, p. 40, 2017, doi: 10.23887/karmapati.v6i1.9267.

[21] I. Marzuki, "Perancangan dan Implementasi Sistem Keamanan Jaringan Komputer Menggunakan Metode Port Knocking Pada Sistem Operasi Linux," J. Teknol. Inf. Indones., vol. 2, no. 2, pp. 18-24, 2019, doi: 10.30869/jtii.v2i2.312.

[22] S. Teknologi, A. Pengendalian, U. Port, O. S. Keaman, and R. Muzawi, "SATIN - Sains dan Teknologi Informasi Aplikasi Pengendalian Port dengan Utilitas Port Knocking untuk,” no. January, 2018.

[23] Muntahanah, Y. Darnita, and R. Toyib, "Paper Block Akses Browsing Menggunakan Mikrotik Rb 751U-2Hnd Dengan Schedule Time (Studi Kasus: Disnakerpora Kota Bengkulu)," J. Sist., vol. 7, no. 2, pp. 64-77, 2018.

[24] D. Adhi Laksono, "Desain dan Implementasi Firewall dengan Layer 7 Filter Pada Jaringan Teknik Elektro," Semin. TA, vol. 2, no. Jaringan Komputer, pp. 1-7, 2012. 